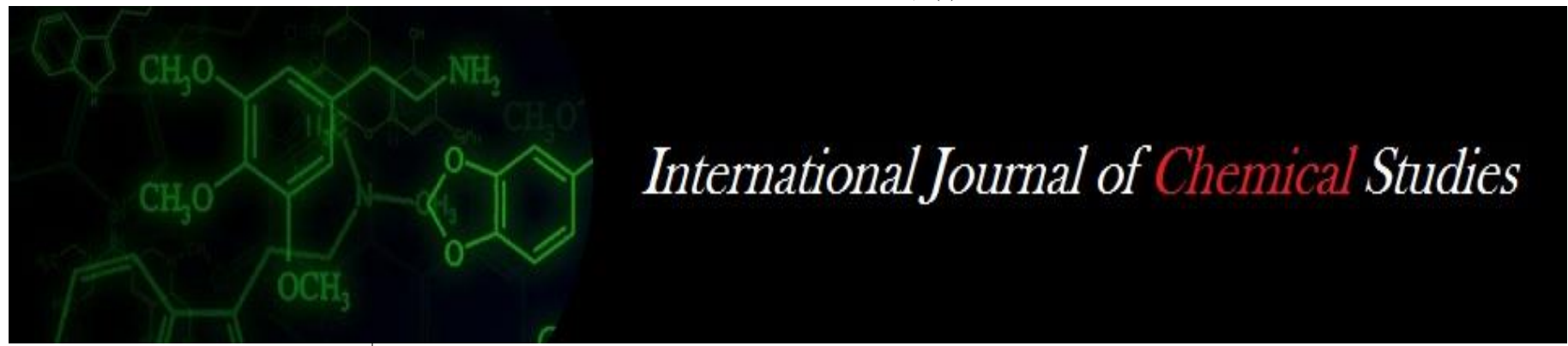

P-ISSN: 2349-8528

E-ISSN: 2321-4902

www.chemijournal.com

IJCS 2020; 8(5): 1116-1121

(C) 2020 IJCS

Received: 15-07-2020

Accepted: 25-08-2020

Ashu Jaswal

Department of Agronomy,

School of Agriculture, Lovely

Professional University,

Jalandhar, Punjab, India

Dr. Sandeep Menon

Lovely Professional University,

Jalandhar, Punjab, India

\section{Review of literature on effect of various herbicidal treatments on chickpea (Cicer arietinum. L) Intercropping with lentil (Lens culinaris Medik.)}

\author{
Ashu Jaswal and Dr. Sandeep Menon
}

DOI: https://doi.org/10.22271/chemi.2020.v8.i5p.10443

\begin{abstract}
This research is based on the effect of various herbicidal treatments on Lentil (Lens culinaris Medik) intercropping with Chickpea (Cicer arietinum L). This study investigated the effect of different herbicides treatments and hand weeding (once, twice and repeated) in comparison with weedy control and weedy check. In both growing season, data were collected on the density and dry weight of weed species, density of lentil, seed yield, total crop biomass, and harvest index of crop. Herbicides ability in controlling weeds depending on the weed species present. Application of Pendimethalin@ $1.0 \mathrm{~kg} / \mathrm{ha}$ as pre emergence herbicides demonstrated better for weeds control and gives high yield per unit area, effectively control weeds in lentil and chickpea. Prometryn and Metribuzin are inhibitors of photosynthesis and are generally used at pre emergence or sometimes used as a post emergence. When these herbicides are used as pre emergence, they are absorbed through the plant shoots while they are still underground and kill or injure the shoots before they rise from the soil surface. Yield losses of 40-80\% have been observed due to weed infestation in lentil and also in chickpea weed have been notice one of the major factors as their losses ranged between 11 to 57\%.In this study, the efficacy of some herbicides estimated in comparison with weedy control in lentil and chickpea and this research also carried out to study the effect of various herbicidal treatments, including chemicals such as Metribuzin and Sethoxydim, in controlling weeds in naturally infested fields of chickpea and lentil in Punjab.
\end{abstract}

Keywords: Herbicide, efficiency, treatments, weed control, competition, interfere etc.

\section{Introduction}

Chickpea (Cicer arietinum L.) and Lentil (Lens culinaris Medik.) are most important crops of agriculture in North Africa and West Asia; (Nygaard and Hawtin, 1981; Williams and Singh, 1987) ${ }^{[5,4]}$ reported that Chickpea and lentil provides valuable protein and other mineral sources in the human diet.Acc.to (Haddad, 1984; Haddad and Arabiat, 1985) ${ }^{[1]}$, Jordan, the yield of chickpea and lentil are lowest in the world wide because of abnormal and poor rainfall and also due to unimproved management practices or production practices which gives quite awareness to timely control of weeds (Haddad, 1984, 1986). Among Rabi crops chickpea and lentil are most important pulses crops mainly grown on marginal and sub-marginal areas of Western Uttar Pradesh without any weed management practices. (Phogat et al. 2003) ${ }^{[6]}$ reported that the yield of lentil reduces due to weeds up to $73 \%$.There are various obstacles such as discarded soil, lack of improved varieties, poor fertilization, diseases, insect\& pest attack and poor weed management practices which leads to reduces the yield of lentil and chickpea. In global production of lentil Turkey ranks third in position following by India and Canada (FAO, 2014) ${ }^{[17]}$. Red lentil were grown in Turkey on an area of 214.788 hectare with 410.000 tons a year production (TUK, 2014).

Anonymous, 2011 reported that the most important plant protection in lentil is cultivation follows: Lentil seed beetles (Bruchus ervi Fröhl, Bruchus lentis Fröhl.)], wilt disease in lentil (Fusarium oxysporum) f.sp lentis (Vasudeva and Srinivasan), weeds such as Broomrape (Orobanche sp.), and wild mustard (Sinapis arvensis L.) (Gilli, 1982) ${ }^{[19]}$ reported that thirty seven spp. of broomrape were recorded in Turkey. (Zare and Dönmez 2013) reported that the species of broomrape near about thirty nine when two species were added to the weed flora of Turkey belonging to the genus Orobanche.
Ashu Jaswal

Department of Agronomy, School of Agriculture, Lovely Professional University, Jalandhar, Punjab, India 
Therefore, the plants of Brassica family are known to limiting the growth of weeds in lentil and chickpea field. For example, (Narwal, 1999) ${ }^{[18]}$ reported that when the some of Brassica family is mixed into the soil it should reduces the growth of some weeds, such as Canola (Brassica napus L.) leaves limiting the growth of red pigment (Amaranthus retroflexus L.), common goosefoot (Chenopodium album L.) and barnyard (Echinochola crusgalli L.). Similar population is effective to the standard herbicide application to control the weed growth.

(Uludag et al. 2006) suggested that the among the Brassica spp. garden radish (Raphanus sativus) has been reported to the best control of Johnson grass (Sorghum halepense) weed in Turkey. The Brassica families are most important to control the weeds and studied about the allelopathic potential of weeds. The germination of 25 weeds and 32 crop species is due to the effect of garden radish extract (Uygur et al. 1990). They reported that the extract of garden radish completely reduces the germination of 11 weeds such as, Sorghum halepense, Alhagi sp., Alopecurus myosuroides, Convolvulus arvensis, Capsella bursapastroris, Cuscuta sp., Hirschfeldia incana, Daucus carota, Ochtodium aegyptiacum and 4 other crop spp. were reported by (Uygur et al. 1990) such as lettuce, tobacco, beans, legumes and clover.

According to (FAOSTAT 2008), examined that among legumes grain lentil ranks sixth in production after chickpea, faba bean, dry beans, pea, and cowpea, and (Sarker and Erskine 2006), suggested that oldest domesticated plants are known as humanity.

(ICARDA, 1985a, Bhan and Kukla, 1987) ${ }^{[27]}$ the yield losses between 40 to $94 \%$ in the subcontinent of India, among 40 to $75 \%$ yield losses due weeds in West Asia (ICARDA, 1982a to 1986a),13-98\% in North Africa (El-Brahli, 1988; Knott and Halila, 1988; [9, 14], ICARDA, 1982a to 1986a) ${ }^{[12]}$, and (Calcagno et al. 1987) ${ }^{[10]}$ reported that $35 \%$ yield loss in Italy.17-105\% yield increase by using effective methods of weed control in chickpea (ICARDA-FSP, 1986) ${ }^{[12]}$.

(Saxena, 1987) ${ }^{[4]}$ Suggested that in winter sown chickpea weeds are serious problem to many farmers because of lack of knowledge and having lack of suitable management practices to reduce the population of weeds of winter sowing the crop should be planted at high density population, early stage of growth, which makes inter row cultivation impossible.

(Phatak et al. 1979) ${ }^{[31]}$ were reported that metribuzin @ 0.21$0.42 \mathrm{~kg} / \mathrm{ha}$ cause less damage in lentil crop and cause less phytotoxicity than equivalent rate of dinoseb amine. (Cessna et al. 1980) suggested that the preplant incorporated treatment of triallate and herbicide residue did not more than 20ppb.According to (Agriculture Canada 1975) at Brandon it was reported that lentil crop was tolerance to EPTC. (Manitoba Agriculture 1984) demonstrated that the post emergence application of diclofop methyl and Metribuzin are suggested at Manitoba for effective control of weeds in lentil. (Bhan et al., 1987; Gollojeh et al. 2013) ${ }^{[8,26]}$ reported that hand weeding is a traditional method of weed management in most of the areas but it is not applicable in large areas because it requires more labor and expensive operation (Mohamed et al., 1997) ${ }^{[28]}$. (Skrobakova et al. 1999) ${ }^{[29]}$ demonstrated that for complete reduction of broadleaf could be control by the application of post emergence herbicides; ethofummesate and pyridape in chickpea and lentil and it also reduces the phytotoxicity in the crops. (Mojeni et al. 2005) examined that for good weed control in chickpea and lentil the treatments of pendimethalin+one hand weeding and trifluralin+one hand weeding, pendimethalin+pyridate compare with control which is most suitable treatment in lentil for weed control. In the present studies quantify that pre and post emergence herbicides treatments and hand weeding is beneficial and attentive method of weed control in lentil and chickpea.

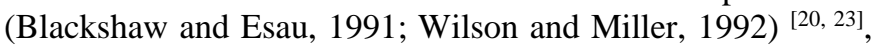
reported that the application of post emergence herbicides such as Imazathapyr and imidazolinone herbicides were effectively control annual grasses weeds and broad leaved weeds, which involve cruciferous species and soybean (Swanton and chandler 1990; Baysinger and Simms, 1992) ${ }^{[22]}$. Baysinger and Simms, 1992) ${ }^{[22]}$. However, selectivity of flurtamone and Imazathapyr in lentils has not been evaluated.

\section{Review of Literature \\ Effect on weeds}

The major weeds in lentil and chickpea were recorded in an experimental field such as Chenopodium album, Phalaris minor, Coronopus didymus, Anagallis arvensis, and Convolvulus arvensis and some other minor weeds effect the growth of lentil and chickpea. Among the weed flora the annual dicot weeds were dominant throughout the season. In weed free treatments the yield of lentil and chickpea more than the herbicide treated plots, on an average $37.7 \%$ yield reduction is occur because of weed infestation. All treatments of weed management practices has been verify to be superior to weedy check in limiting the dry matter and weed density at 90 DAS. It was recorded that the pendimethalin@ 0.75kg $/ \mathrm{ha}$ applied as pre emergence + One hand weeding causes lowest weed density (4.m sq) and dry weight $(2.64 \mathrm{~g} / \mathrm{m} . \mathrm{sq})$ as par pendimethalin applied $1.0 \mathrm{~kg} / \mathrm{ha}$ as pre emergence lower than that of the treatments, including isoproturon dose with or without hand weeding. If seed rate increased $25 \%$ denoting decrease in weed dry matter $(32 \%)$ with respect to other treatments respectively. Maximum weed control efficiency (94.1\%) was recorded in pendimethalin applied plot @ $0.75 \mathrm{~kg} / \mathrm{ha}+$ one hand weeding with respect to pendimethalin $1.0 \mathrm{~kg} / \mathrm{ha}$ this may be attributed restrict the seed germination examined by Singh et al. (1994) ${ }^{[25]}$ and Jain (2007) ${ }^{[24]}$.

\section{Effect on Crop}

Weeds affected the crops which influence reduction in the yield of crop such as lentil and chickpea also decrease the yield attributes of lentil crop. The maximum grain yield was obtained from the pendimethalin $(0.75 \mathrm{~kg} / \mathrm{ha})+$ one hand weeding plots about $1.66 \mathrm{t} / \mathrm{ha}$ as with pendimethalin $1 \mathrm{~kg} / \mathrm{ha}$ as weed free and verify best over other of the treatments with grain yield respectively. Yet, same observations were observed in straw yield of these crops. There should be increased in $25 \%$ seed rate which impacts the straw and grain yield of crops with respect to other treatments. By increasing the $25 \%$ of seed rate it was examined that increase in yield about $22.8 \%$ therefore; the incremental increase in yield was reported in one hand weeding with increase seed rate about $25 \%$ which gives yield $19.26 \%$ and $40.87 \%$, respectively.

\section{Weed Flora}

A single herbicide may control the specific weed species not other weed species. In comparison with other crops there is no particular weed flora in chickpea. The certain association weeds species with field crop chickpea and lentil such as climate, soil, adaptation, soil type and its fertility, time of sowing, rotation of crop per year, insect\& pest management, water management, weed management.

(Calcagno et al., 1987; El-Brahli, 1988) [10, 9] Was demonstrated that there are more than 75 species of weeds 
affected the chickpea field every year in Mediterranean region. These weed species belong to 26 different families and weed species are mostly dicotyledons.

(Graf et al. 1982) was examined the parasitic weed species in chickpea are Orobanche crenata, Cuscuta campestris, O. egyptiaca and (Vyas and Joshi, 1975) was reported weed sp. C. hyaline.

(Krishnamoorthy et al. 1977) was reported that for the proper germination of Orobanche spp. seed chickpea is to be known as effective crop.

\section{Weed competition}

According to Bhan and Kukla, (1987) ${ }^{\text {[27] }}$ was reported that competition of weeds is uniformly equal in irrigated and rainfed chickpea. There has been many studies done on weeds in chickpea crop, but the weed competition in chickpea have limited. Weed species which occur in the chickpea crop this spp. badly effect the growth of the crop, nutrient requirement, water management and also other growth parameters therefore; it decreases the yield of crops. For example, such as Chenopodium was more competitive than the Polybigen and Avena ludoviciana in North Syria.

\section{Effective herbicides}

There are different herbicides which control the weeds effectively in lentil and chickpea. Such as Pre Plant herbicides and soil incorporated herbicides (PPI) which consist of fluchloralin, oxyfluorfen, trifluralin and triallate etc. By the application of Pre emergence and Post emergence herbicides weed population should be reduce which helps to increase in yield of grain. Some pre emergence herbicides, for example:Cyanazine, alachlor, dinoseb amine, Prometryn, Terbutryn etc.Post emergence herbicides are Fluazifop-p-butyl, fenoxaprop-ethyl and dinoseb-acetate. Herbicides application needs more care when applied in field, different growth stages of crops and air temperature to avoid phytotoxicity.

(Ma et al. 2004) was reported that Fluazifop-p-ethyl and fluazifop-p- butyl used as a post emergence herbicides to control grassy weeds in the chickpea and lentil field these both herbicides inhibit the synthesis of enzymes required for lipid synthesis.

(Graf et al. 1982) was reported that Cuscuta campestris was effectively controlled by the application of pre emergence herbicide Pronamide with chlorthal dimethyl.

(ICARDA, 1981 to 1986) ${ }^{[12]}$ and Chickpea International Weed Control Trial (CIWCT) tested in 1980-1981 in different countries of WANA region develop best treatments for controlling weeds such as Pre and Post emergence herbicides application. Pre emergence herbicides such as Chlorobromuron (1.5-2.5 kg/ha), Terbutryn (2.5- $4.0 \mathrm{~kg} / \mathrm{ha})$ and Methabenzthiazuron $(0.5 \mathrm{~kg} / \mathrm{ha})$, also alone or in combination with Pronamide $(0.5 \mathrm{~kg} / \mathrm{ha})$. Post emergence application of Fluazifop-butyl $(1.0 \mathrm{~kg} / \mathrm{ha})$ are best for controlling grasses weed in chickpea and lentil when grasses weeds are 10-15 cm tall in height. For annual, grasses and broad leaf weeds in cereals crops best control was reported in Algeria and Northern Syria Cyanazine (0.5-1.0 kg/ha) with Pronamide $(0.5 \mathrm{~kg} / \mathrm{ha})$.

The farm trials in Northern Syria during the years of 19851986 weeds control by the application of pre emergence herbicides Terbutryn $(2.0 \mathrm{~kg} / \mathrm{ha})$ with Pronamide $(0.5 \mathrm{~kg} / \mathrm{ha})$ which increase the yield of lentil and chickpea about $26 \%$ and $6 \%$ in winter sowing of crop with comparison to control.

In Turkey 12 herbicides were used in lentil for controlling the weeds under dry land conditions. Linuron and Prometryn were used for effective weed control; these herbicides increased the yield of lentil about $49 \%$, also increase the total biomass without any noxious effect on lentil reported by (Elkoca et al. 2005).

(Haddad, 1984; Haddad and Arabiat, 1985) [1] In Jordan reported that world wise the yield of lentil and chickpea were least and the production were not satisfactory for full fill the human consumption because of low yield.

\section{Response of different weed species to herbicides}

(El-Brahli, 1988) ${ }^{[9]}$ Reported that Prometryn (1.0 kg/ha) and Terbutryn $(3.0 \mathrm{~kg} / \mathrm{ha})$ were effectively control Chenopodium and Ridolfia segetum, Amaranthus sp. and Torils nodosa. Prometryn and Terbutryn was effectively control the weed sp. (Calagno et al. 1987) in Italy reported that Terbutryn did not control Vicia sativa completely. Pre emergence application of Nitrofen-linuron, linuron, Penoxalin control almost accepted weeds sp. in chickpea and lentil. It evident that most effective herbicides do not have very broad spectrum effect on weed sp.

\section{Pre emergence herbicides}

Among all the Pre emergence herbicides pendimethalin @ $1.26 \mathrm{~kg}$ /ha gave better control for controlling weeds by different visual experiments in fields, but also cause delayed germination of crop, stunted growth of plants, dark green color, short internodes, also cause severe crop toxicity.

Other pre emergence herbicides stop the growth of crops, except Tolkan. On an average it was estimated that these pre emergence herbicides control weeds effectively. Broad leaf weeds and grasses generally controlled by Oxadiazon (Ronstar) when weeds are again grow in the end of the crop season, this herbicide control broad leaf weed and grasses about $50-70 \%$ respectively. Due to long lasting persistence of pendimethalin non-significant re-growth of weeds up to the time of crop harvest, which was next to the weed free check (Hand weeding plots).

(Singh et al. 1985) reported that 79-66\% yield of lentil and chickpea should be increased by fluchloralin and methabenzthiazuron $1.5 \mathrm{~kg} / \mathrm{ha}$ as a pre emergence application. Intercropping with wheat and sowing in narrow rows $(30 \mathrm{~cm}$ apart) gave encouraging the yield of crops.

(Singh et al. 1987) demonstrated that for effectively control of weeds application of methabenzthiazuron, fluchloralin and alachlor@ $1 \mathrm{~kg} / \mathrm{ha}$ as pre emergence control weeds effectively to increase the crop of lentil.

(Buhler and Werling 1989) suggested that application of imazaquin@0.07 kg/ha control 95\% grass weeds and 83\% broad leaf weeds.

(Tewari and Trivedi, 1985) reported that pre emergence application of Terbutryn@0.08 kg/ha, oxadiazon@1.0 kg/ha and isoproturon@1.0kg/ha was effectively control weeds growth.

\section{Post emergence herbicides}

Grasses weeds completely controlled by the application of fusilade@0.50 kg/ha and $0.75 \mathrm{~kg} / \mathrm{ha}$ in combination with flex@0.13 kg/ha. Flex alone and or with Fusilade leads to phytotoxicity to chickpea which was almost recovered at the advanced growth stages. Tribunil is suggested for both pre and post emergence application and notice that weed control was approximately same. Therefore, post emergence application of these herbicides cause severe phytotoxicity in crop, which frequently decrease the yield of crops. Fusilade and flex were not constant throughout the crop season. 
Fusilade effectively control the grasses weed can be attributed systematic action which reduces the re- sprouting of the perennial grasses weeds. Stomp, Ronstar, Tribunil, tolkan, fusilade and flex incremental increase in yield by 21.2 to $141 \%$ over control up to eight weeks in chickpea. Fusilade effectively control grasses weeds when it applied in $10-15 \mathrm{~cm}$ height of chickpea.

(Kukula et al. 1985) reported that in winter sown chickpea weed infestation is more than the spring sown chickpea with decrease in yield of $7.5 \%$ accounted in winter sown cv. ILC 482.Spring sown chickpea was more resistant than the winter sown chickpea crop to Orobanche crenata.

Gill and Brar (1977), Gill et al. (1978), Misra and Tosh (1978), and Majeed et al. (1983) were found the similar results. Gill et al. (1978) reported that after first irrigation at 4-5 leaf stage application of Tribunil was not effective against wild oats.

Yadav et al. (1988) observed that Tribunil at both rate 0.75 $\mathrm{kg} / \mathrm{ha}$ and $1.50 \mathrm{~kg} / \mathrm{ha}$ gives higher yield up to $(2.2 \mathrm{t}$ and $2.08 \mathrm{t})$ respectively from chemical control along with basalin@ 0.5 and $1.0 \mathrm{~kg} / \mathrm{ha}(2.07 \mathrm{t}$ for both rates). Fusilade was slightly effective and some phytotoxicity was recorded from Oxadiazon (Ronstar), which was tested @ 0.75-1.50.

All herbicides, gave effective control in lentil and chickpea, increase more than $100 \%$ grain yield except nitrofen, respectively than the unweeded control, on the other hand chloramben and trifluralin authenticate more promising.

(Daulay and Singh, 1982), was reported that alachlor, trifluralin, and nitrofen these herbicides effectively control weeds in chickpea, cluster beans, giving yield equal to that of the hand weeded treatments.

\section{Weed species present in Lentil and Chickpea}

The dominating broad leaf weed species recognize as (Chenopodium album L.), Speedwell (Veronica arvensis L.), Black nightshade (Solanum nigrum L.) and wire weed (Polygonum aviculare L.).

Other broadleaf weeds species were noted Spurrey (Spergula arvensis L.), Scarlet pimpernel (Anagallis arvensis), hedge mustard (Sisymbrium officinale L.), shepherd's purse (Capsella bursa-pastoris L.), scentless chamomile (Matricaria inodora L.), henbit (Lamium amplexicaule L.), broadleaved dock (Rumex obtusifolius L.), white clover (Trifolium repens L.), sow thistle (Sonchus oleraceus L.), wart cress (Coronopus squamatus L.), chickweed (Stellaria media L.), field bind weed (Convolvulus arvensis L.), storksbill (Erodium cicutarium L.).Grasses weeds includes Phalaris aquatica L., canary grass (Phalaris minor L.), annual poa (Poa annua L.), and perennial ryegrass (Lolium perenne L.), they included minor portion in the weed population.

Major weeds of lentil were reported in Pakistan are in maina by (Adamczewski, K and Paradowski, A. 1987), (Medicago denticulata), Senji (Melilotus indica), lehli (Convolvulus arvensis), bathu (Chenopodium album), chattri dodhak (Euphorbia helioscopia), wild oat (Avena fatua), papra (Fumaria indica), Kandiari (Carthamus oxyacantha) (Sultan and Nasir, 2007).

(Saxena and Wassimi, 1980; Al Thahabi et al. 1994) was reported that $40-80 \%$ yield loss is due to weeds in lentil.

\section{Residual effect of herbicides}

(Sheriff et al. 1973) reported that application of diuron to cotton@2-4 kg/ha had an effect on chickpea as a following crop. Sometimes, soil acting used for the antecedent crops in rotation and the chickpea damaged depending on the type of herbicides involved. Some herbicides show residual effects in soil. Thus, it is necessary to check the residual effects for each case.

Alternate cropping pattern following chickpea may also be harmful when soil-acting herbicides used in chickpea. Methabenzthiazuron@2.0kg/ha the legumes phase causes damage to cereals. Pronamide which is used for grass control in legumes is a effective killer but it generally deteriorate within the span between the two crops and hence should not affect the following cereals.

(Haddad, 1988), reported that in Algeria use of trifluralin in chickpea resulted in damage in cereals in succeeding seasons. In high elevation area of Turkey, nevertheless summer temperature is low, there is chance of very severe damage in cereals crop following legumes crops on which Pronamide has been applied, respectively.

\section{Limitation of chemical control}

(Kantar F, Elkoca E, Zengin H 1999) reported that some of herbicides has long lasting effect in soil and causes residual effect for long period of time even though it is not recommended.

Chemicals very quick response to the soil, therefore they applied in the fields but along this quick effect chemicals there have also adverse affect of herbicides on crop plant, soil and our surrounding environment. In the present time we know that $45 \%$ of loss in yield is due to weeds present in the field, however these weed affect the growth of our crop. Therefore, for controlling the weed infestation we use chemical spray to overcome the weed population. Some herbicides are very effective to control the weeds from the crops but some farmers are not able to buy these herbicides because of high price. Some crops are very sensitive to chemical spray such as, chickpea lentil which are sprayed for weed control, hence these herbicides sometimes shows bad effect on crops, respectively.

\section{Result and discussion Chickpea}

Volunteer wheat was dominating in the chickpea experiment along with gramineous weeds. About $70 \%$ reduction in yield of chickpea is due to weed infestation and lack of weed control measures. Cyanazine@ 0-5 kg/ha and Prometryn @ 1 $\mathrm{kg} / \mathrm{ha}$ gave better results and increase in the yield of chickpea rather than the weedy control. The harvest index was also increased by using these herbicides to the control weed. The weeds offered more competition to the crop plants at the reproductive stages, however also reduces the dry matter partitioning to the seeds. Therefore, the better results were found in weed free control followed by one or two weeding. Some herbicides effectively control the weeds, however Cyanazine, Prometryn, Terbutryn reduces the total weed dry weight but did not enough to control grass weeds, specially Avena sterilis and volunteer wheat in the chickpea field. However, only limited increase in yield occur in these treatments in the comparison of weedy control. All these herbicides Fluazifop-butyl, Sethoxydim and Pronamide inhibited the growth of grass weeds and increase the yield of chickpea. Therefore, the yield in weed free treatments is much more than the other treatments, thus the yield levels of other treatments did not reach the level achieved in weed free plots. Volunteer wheat did not control by Diclofop-methyl, however this herbicides only control Avena sterilis respectively. 


\section{Lentil}

In weed free treatments the yield of lentil were always highest. Because of weeds throughout the season of crop, it causes severe reduction in yield about $57 \%$. Therefore, it also decrease the harvest index of crop. Grasses were dominated in the lentil field; therefore both broadleaf weeds and grass weeds were present and effect the growth of lentil. Cyanazine, Methabenzthiazuron and Prometryn @ 1 kg a.i/ha did not increase the yield of lentil; however these herbicides did not control grasses such as Phalaris paradoxa, Avena sterilis and volunteer wheat. Metribuzin decrease the dry weight of lentil respectively, but also damaged the lentil plants in early stages and decrease crop yield below the yield level of the weedy control. Among all the herbicides treatments, the highest yield were achieve in following treatments such as Diclofopmethyl, Pronamide, and Sethoxydim because gramineous weeds dominated the weed flora significantly. The use of herbicide combination increase the yield of lentil and also control weeds effectively over weedy control but none of them resulted in higher yield than those of attain from graminicides alone. None of the herbicide treatments control weeds completely.

\section{Conclusion}

Weed flora and weed density plays a very important role, thus in above concept we discuss about herbicides efficacy, how to apply herbicides and it is important to know how to select proper herbicide or herbicides treatment for the proper eradication of weeds. The herbicides application to control the weeds will not be economic if weed infestation is low because of low weed density, then not need to use herbicides. Therefore, in these cases we can control weeds by hand weeding. In those areas where hand weeding is not over priced, two to three hand weeding at the interval of one to two months after crop emergence could be more effective for controlling weeds and this method easy to adopt. In case of herbicide application it required greater technical skill to use in the field. Likewise, both grain and straw of chickpea and lentil plays a important part in human food chain the use of unregistered herbicides, shown to be effective in these studies, should suggested only after it has been proven that there are no toxic residue produce from crops treated with these chemicals. Cyanazine, metribuzin, cyanazine plus metribuzin in combination therefore, chickpea shows tolerance to these herbicides when applied as a pre emergence and post emergence application of Haloxyfop and clethodim respectively. Haloxyfop and clethodim control only grass weeds, however crop losses is due the competition of broadleaf weeds.

\section{References}

1. Haddad N. Chickpea production in Jordan. In M. C. Saxena and K. B. Singh (eds) Ascochyta Blight and Winter Sowing of Chickpea pea (The Hague: Martinus Nijhoff/Dr W. Junk Publishers), 1984, 211-218.

2. Haddad N. [Recommendation about lentil farming in Jordan]. Extension Bulletin No. 3 (Amman, Jordan: Faculty of Agriculture, University of Jordan) [in Arabic], 1986.

3. Haddad N. Chickpea weed control trial. In Food Legume Improvement Project in Collaboration with IDRC, Annual Report 1983/84 (Amman, Jordan: Faculty of Agriculture, University of Jordan), 1983, 68-70.

4. Williams PC, Singh U. The chickpea-nutritional quality and evaluation of quality in breeding programme. In M.
C. Saxena and K. B. Singh (eds) The Chickpea (Aleppo, Syria: International Center for Agricultural Research in the Dry Areas), 1987, 329-356.

5. Nygaard DG, Hawtin GC. Production, trade and uses. In C. Webb and G. Hawtin (Eds) Lentil (London: Commonwealth Agricultural Bureaux), 1981, 7-13.

6. Phogat SB, Kumar S, Sangwan N, Hooda RS. Effect of herbicides and cultural practices on weed flora of lentil. Indian Journal of Pulses Research. 2003; 16(2):119-121.

7. Turk MA, Tawaha AM. Effect of time and frequency of weeding on growth, yield and economics of chickpea and lentil. Research on Crops. 2001; 2(2):103-107.

8. Bhan VM, Kukula. Weeds and Their Control in Chickpea. In the chickpea (Sexena, M.C and Singh, K.B., Eds.). C.A.B. International, Wallingford. Oxen, U.K, 1987, 319-328.

9. EL-BRAHLI E. Lutte Contre Les Mauvaises Herbes Dan's la Lentille ET Le Pois-Chiche D'Hiver En Zone Semi.Aride. In Proceeding of the Seminar on Food Legumes in Morocco, Settat, April 7-9, 1987. INRA/CARDA, 1988.

10. Calcagno F, Gallo Venora G, Restuccia G. Primi resultati di recherché sperimentali sul diserbo chimico Del cece. In la Coltura Del Cece in Italia.ENEA, Atti della giornata tenutasi press il Centro Ricerche Energia Della Casaccia, Roma, Italy, 1987.

11. ICARDA. (International Center for Agricultural Research in the Dry Areas): International Nursery Reports of Food Legume Improvement Program. No. 5 to Aleppo, Syria, 1981a-1987a.

12. ICARDA-FSP. (International Centre for Agricultural Research in the Dry Areas - Farming System Program) Annual Report. Aleppo, Syria, 1986.

13. INRAT/ICARDA. Tunisia-ICARDA Cooperative Program on Food Legume Improvement. Progress Reports, 1984/85 and 1985/85. ICARDA, Aleppo, Syria, 1985, 1986.

14. Knott CM, Halila MH. Weeds in food legumes-problems, effects and control methods. In World Crops, Cool season Food Legumes (Summerfield, R.J., ed.). Proceeding of Interntional Conference on Food Legumes Research, July 6-11, 1986. Spokane, Washington, USA, 1988.

15. Sheriff RA, Humsiji G, Krishnashastry KS. Weed control in cotton by herbicides and their residual toxicity to succeeding crops. Mysore Journal of Agricultural Science. 1973; 7:588-596.

16. Anonymous. Mercimek entegre mücadele teknik talimat1. (Instruction of integrated pest management techniques in lentil). Republic of Turkey Ministry of Food, Agriculture and Livestock, Ankara, 2011, 76p.

17. FAO. Food and Agriculture Organization of the United Nations, 2014. http://faostat3.fao.org/faostatgatewa (Access date: 04.12.2014).

18. Narwal SS. Allelopathy in weed management. Allopathy Update, Basic and Applied Aspects (Eds: SS Narwal). 1999; 2:204-254.

19. Gilli A. Orobanche L. In: Flora of Turkey and the East Aegean Islands (Ed. Davis P.H.). Edinburgh at the University Press. 1982; 7:3-23.

20. Blackshaw RE, Esau R. Control of annual broadleaf weeds in pinto beans (Phaseolus vulgaris). Weed Technol. 1991; 5:532-538.

21. Vincell WK, Wilson HP, Hines TE, Hatzios KK. Common lambs quarters (Chenopodium album) and 
rotational crop response to Imazethapyr in pea (Pisum sativum) and snap bean (Phaseolus vulgaris). Weed Technol. 1990; 4:39-4.

22. Baysinger JA, Simms BD. Giant ragweed (Ambrosia trifida) control in soybean (Glycine max). Weed Technol. 1992; 6:13-18.

23. Wilson RG, Miller SD. Dry edible bean (Phaseolus vulgaris) response to Imazethapyr. Weed Technol. 1992; 5:22-26.

24. Jain VK. Integrated Weed Management in lentil (Lens culinaris Medik.). M.Sc. Ag. Thesis, Deptt. of Agronomy, S.V.P. University of Agriculture \& Tech., Meerut (UP) India, 2007.

25. Singh G, Mehta RK, Singh OP. Weed control in lentil under rainfed low land conditions. Indian Journal of Pulses Research. 1994; 7(2):132-136.

26. Gollojeh KS, Ebadi A, Mohebodini M, Sabaghnia N. Herbicide effects on weed control and yield of lentil (Lens culinaris Medik) in dry land condition. Natura Montenegrina, Podogorica. 2013; 12(1):151-163.

27. Bhan M, Kakula S. Weeds and their control in chickpea. In: Sexana, C., and K.B. Singh (eds.) Chickpea, CAB, ICARDA, Aleppo, Syria. 1987, 319-325.

28. Mohamed ES, Nourai AH, Mohmamed GE, Mohamed MI, Saxena MC. Weeds and weed management in irrigated lentil in Northern Sudan. Weed Res. 1997; 37:211-218.

29. Skrobakova E. The effect of post-emergence treatment with herbicides on the yield of chickpea. Vedecke-Prace Vyskumneho-Utavu-Rastlinnej Vyroby-Piest'any. 1999; 29:61-66.

30. Ahlawat IPS, Singh A, Saraf CS. Competitive efficiency of cultural and herbicides methods of weed control in Bengal-gram (Cicer arietinum L.). Indian Journal of Weed Science. 1978; 10:1-8.

31. Ahlawat IPS, Singh A, Saraf CS. Studies on weed control.In lentils. LENS Newsletter. 1979a; 6:19-21. 